\title{
Hunger without borders
}

As humanitarian and UN agencies scramble to catch up with the food crisis in Niger, neighbouring Mali, Mauritania and Burkina Faso warn that they will soon face similar crises.

Drought, locusts and flooding have created a shortage of food for about one-third of Niger's 11.7 million residents, including 800000 children under 5, 32000 of whom are severely malnourished.

In Mali more than 1 million people face food shortages, Mauritania is close behind with 800000 residents at risk, and in Burkina Faso 500000 people are in crisis.

"Mali is just as bad [as Niger] and while the money is finally coming through for Niger, Mali only has $14 \%$ of the money it " needs," says Mia Vukojevic of ○ Oxfam Canada.

\section{News@ a glance}

HIV jump: More than 6 million of South Africa's 40 million citizens may be infected with HIV, up from previous estimates of 4.5 million, states the country's health department. - India has the second highest overall number of people living with the disease. An estimated 5.1 million Indian people $38 \%$ of them women - live with HIV, an increase of 500 000 from 2002. In the US, the number of people living with HIV surpassed 1

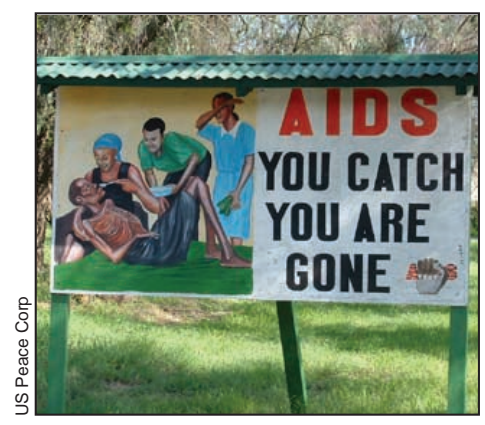
million for the first time in June, according to the Centers for Disease Control and Prevention. The infection is more prevalent among men, at $74 \%$. In Canada, 56523 positive HIV tests
Aid organizations are particularly concerned because assistance to Niger was so slow in coming. An initial Niger government appeal in November 2004 went largely unheeded. A UN appeal in March raised about US\$1 million and a renewed appeal in May netted US\$10 million.

The most urgent need now is for medical and nonmedical volunteers, says Marilyn McHarg, Operational Director for Médecins Sans Frontières (MSF).

In mid-August the situation in Niger was "unmanageable," says McHarg. Personnel admitted 120 people in just 1 night; 7 were dead by morning.

Up to 1600 children arrive weekly at MSF's 6 inpatient and 26 outpatient therapeutic feeding centres. Since January, MSF has treated 16000 Niger children for severe malnutrition and expects to treat more than 30000 by year's end.

With no social safety net, "the shortages hit the poorest of the poor," says Dr. Milton Tectomidis, a Montréal-based nutritional adviser who worked with MSF in Maradi, near the Nigerian border, for 6 weeks. Paradoxically, there is still food in the market, but people can't afford to buy it. This "free market condemns $30 \%$ of the population to hunger."

Niger is the second poorest country in the world according to the UN; more than $60 \%$ of its residents live with less than US\$1 per day. Both Tectomidis and McHarg worry the problem will worsen. "We need to supplement [feeding] before people need end-stage therapeutic feeding centres," says McHarg. — Sally Murray, CMAJ were reported to the Centre for Infectious Disease Prevention and Control between November 1985 and June 2004. The annual number of reports has increased from 2112 in 2000 to 2499 in 2004.

Avian flu vaccine: US researchers have successfully tested an avian influenza vaccine in healthy volunteers. The New York Times (Aug 7, 2005) reported high doses of the vaccine produced antibody responses to the $\mathrm{A}(\mathrm{H} 5 \mathrm{~N} 1)$ strain of avian influenza virus in preliminary trials conducted by the National Institute of Allergy and Infectious Diseases. More tests are needed to determine optimal doses. Final study results will not be published until the trial is complete. The $\mathrm{A}(\mathrm{H} 5 \mathrm{~N} 1)$ strain has been responsible for killing 57 people to date. Health officials worldwide, fearing an avian influenza pandemic, are rushing to develop mass vaccination plans for the virus. - Sally Murray, CMAJ

e-Health Canada: Health Canada has launched MedEffect (www .healthcanada.gc.ca/medeffect) to centralize health product safety information. The site includes access to Health Canada's advisories, warnings and recalls, the Canadian Adverse Reaction Newsletter and the Canadian Adverse Drug Reaction Monitoring Program Online Query and Data Extract. Health Canada has also redesigned its Web site (www .healthcanada.gc.ca) to make it easier to search and use. More than 60000 pages are now organized by subject, rather than departmental structure. - Compiled by Barbara Sibbald, CMAJ 